\title{
STRES PASCA TRAUMA PADA IBU POST PARTUM DENGAN SECTIO CAESAREA EMERGENCY DAN PARTUS SPONTAN
}

\author{
Yuliati Amperaningsih*, Purwanti Nugrahanti Siwi** \\ *Jurusan Keperawatan Poltekkes Tanjungkarang \\ **Rumah Sakit Mardi Waluyo Metro Lampung
}

\begin{abstract}
Angka persalinan sectio caesarea di Provinsi Lampung tahun 2013 menurut hasil Riskesdas sekitar 4,5\%. Berbagai masalah psikologis yang dialami ibu bersalin di rumah sakit sangat memerlukan perhatian dan perawatan yang optimal dari seorang perawat/bidan dan keluarganya. Berdasarkan data rekam medis Rumah Sakit Mardi Waluyo Metro tahun 2016 terdapat 289 (78,3\%) persalinan sectio caesarea dan 80 persalinan normal $(21,68 \%)$ dari 369 persalinan. Tujuan dari penelitian ini adalah diketahui perbedaan kejadian stres pasca trauma pada ibu post partum dengan sectio caesarea emergency dan partus spontan. Jenis penelitian kuantitatif, desain penelitian analitik pendekatan cross sectional. Populasi semua pasien post partum primigravida 60 orang yang terdiri dari $30 \mathrm{ibu}$ post partum SC emergency dan 30 ibu post partum normal, sampel 60 responden. Analisa data menggunakan uji t-Independen. Hasil penelitian menunjukkan rata-rata tingkat stress pasca trauma pada ibu yang melakukan persalinan dengan Sectio Caesar emergency adalah 16,7, dengan SD 4,95. Rata-rata tingkat stress pasca trauma pada ibu yang melakukan persalinan dengan persalinan normal adalah 16.7, dengan SD 3,39. Ada perbedaan kejadian stres pasca trauma pada ibu post partum dengan sectio caesarea emergency dan partus spontan di Rumah Sakit ( $p$-value 0,000). Disarankan dilakukan intervensi khusus seperti penyuluhan dan pendampingan untuk menurunkan derajat stres pasca persalinan pada pada perempuan postpartum.
\end{abstract}

Kata kunci: stres, sectio caesarea emergency, partus spontan

\section{LATAR BELAKANG}

Derajat kesehatan masyarakat dinilai dengan menggunakan beberapa indikator yang mencerminkan kondisi mortalitas (kematian), status gizi, dan morbilitas (kesakitan). Derajat kesehatan masyarakat di Indonesia digambarkan melalui angka mortalitas yaitu Angka Kematian Ibu (AKI), Angka Kematian Neonatal (AKN), Angka Kematian Bayi (AKB), dan Angka Kesakitan Balita (AKBA), Umur Harapan Hidup, dan Angka Morbilitas (Kemenkes RI, 2015).

Menurut laporan World Health Organization (WHO) tahun 2014 AKI di dunia yaitu 289.000 jiwa. Amerika Serikat yaitu 9300 jiwa, Afrika Utara 179.000 jiwa, dan Asia Tenggara 16.000 jiwa. AKI di negara-negara Asia Tenggara yaitu Indonesia 214 per 100.000 kelahiran hidup, Filipina 170 per 100.000 kelahiran hidup, Vietnam 160 per 100.000 kelahiran hidup, Thailand 44 per 100.000 kelahiran hidup, Brunei 60 per 100.000 kelahiran hidup, dan Malaysia 39 per 100.000 kelahiran hidup (WHO, 2014).

Salah satu sasaran yang ditetapkan Rencana Pembangunan Jangka Menengah Nasional (RPJMN) tahun 2010-2014 dalam bidang Kesehatan adalah menurunnya AKB menjadi 23/1.000 KH dan AKI menjadi 118/100.000 KH. Namun kenyataannya dari hasil SDKI 2012, AKB mencapai angka 32/1.000 KH dan AKI 359/100.000 KH. Hal ini memperlihatkan bahwa tidak terdapat penurunan angka-angka kematian, sehingga target RPJMN tahun 2010-2014 mengenai AKI dan AKB maupun untuk Sustainable Development Goals (SDGs) tahun 2030 diperkirakan akan sulit tercapai.

Meskipun $90 \%$ persalinan termasuk kategori normal atau tanpa komplikasi persalinan, namun apabila terjadi komplikasi maka penanganan selalu berpegang teguh pada prioritas keselamatan ibu dan bayi. Operasi sectio caesarea ini merupakan pilihan persalinan 
yang terakhir setelah dipertimbangkan cara-cara persalinan pervaginam tidak layak untuk dikerjakan (Mulyawati, 2011).

Angka persalinan sectio caesarea di Provinsi Lampung tahun 2013 menurut hasil Riskesdas sekitar 4,5\%. Angka kejadian sectio caesarea di Kota Bandar Lampung pada tahun 2012 adalah 3.401 dari 170.000 persalinan 20\% dari seluruh persalinan (Dinkes Provinsi Lampung, 2012).

Berbagai masalah psikologis yang dialami ibu bersalin di rumah sakit sangat memerlukan perhatian dan perawatan yang optimal dari seorang perawat/bidan dan keluarganya. Menjadi sangat penting peran perawat/ bidan dan dukungan keluarga dalam membantu ibu untuk beradaptasi dengan perubahan psikis setelah melahirkan terutama yang mengalami stres pasca trauma akibat prosedur pertolongan persalinan di rumah sakit.

Satu dari sepuluh bayi berusia 6 sampai 9 bulan diasuh oleh ibu yang mengalami gangguan jiwa dan $2,8 \%$ ibu memenuhi kriteria diagnostik untuk post traumatic stress disorder pada enam minggu setelah melahirkan, kemudian akan menurun menjadi $1,5 \%$ setelah enam bulan, yang melahirkan dengan cara spontan, seksio sesaria, maupun ekstraksi vakum. Lovelan-Cook, et al (2004) menjelaskan bahwa sekitar $7,7 \%$ wanita, setelah melahirkan memenuhi kriteria diagnostik untuk mengalami post traumatic stress disorder dengan gangguan mood dan kecemasan.

Beberapa penelitian telah dilakukan di Indonesia mengenai depresi postpartum, penelitian Hamid (1997), yang menemukan bahwa sekitar 30\%-80\% wanita mengalami gejala kemurungan setelah melahirkan, $20 \%$ mengalami depresi pasca melahirkan. Adapun kemurungan yang dimaksudkan adalah berupa kesedihan, menangis, sangat lelah, mudah tersinggung, dan sulit konsentrasi. Kondisi ini dapat dipengaruhi oleh faktor biologis dan faktor psikologis termasuk sikap negatif mengenai mengasuh anak, riwayat kehidupan menegangkan, perkawinan yang tidak harmonis, dan kurangnya dukungan keluarga.

Menurut Sussman (2000) yang menjelaskan bahwa pengalaman melahirkan adalah suatu masa krisis di mana proses persalinan merupakan kondisi yang menegangkan dan mencemaskan bagi wanita dan keluarga, terutama persalinan dengan tindakan bedah. Sejumlah $8-12 \%$ wanita tidak dapat menyesuaikan peran menjadi orang tua dan menjadi sangat tertekan sehingga mencari bantuan tenaga kesehatan.

Menurut Czarnocka dan Slade (2000), prevalensi dan perjalanan penyakit post traumatic stress disorder selama kehamilan dan pasca kelahiran (post partum) tidak mendapat cukup perhatian. Dokumentasi laporan mencatat bahwa pengalaman traumatik obstetrikal seperti proses melahirkan, kelahiran, keguguran, kematian janin, bayi lahir mati adalah sebagai pendorong simtomatologi yang berkaitan dengan trauma.

Menurut Shinto (2007, dalam Evariny, 2007), bahwa apabila beban trauma terus berlanjut, dampaknya akan berbekas pada janin. Terlebih jika ibu sampai mengalami stres. Oleh karena itu, ibu hamil sebaiknya bukan hanya memperhatikan bagian kesehatan fisiknya saja, melainkan juga kesehatan psikologisnya.

Berdasarkan data rekam medis Rumah Sakit Mardi Waluyo Metro tahun 2014 kasus persalinan Sectio caesarea sebanyak $234(71,3 \%)$ dan $94(28,7 \%)$ persalinan normal dari 328 persalinan, tahun 2015 terdapat peningkatan kasus sebanyak $285(76 \%)$ dan 90 persalinan normal $(24 \%)$ dari 375 persalinan dan tahun 2016 terdapat $289 \quad(78,3 \%)$ persalinan sectio caesarea dan 80 persalinan normal $(21,68 \%)$ dari 369 persalinan (RS Mardi Waluyo, 2016), berdasarkan observasi peneliti diketahui bahwa sebagian besar ibu post partum terutama persalinan Sectio caesarea emergency menunjukkan gejala stress pasca trauma yaitu mudah marah, mudah kesal, mudah tersinggung, sulit untuk relaksasi, dan tidak sabaran. 


\section{METODE}

Jenis penelitian ini adalah penelitian kuantitatif dengan desain analitik observasional yang menggambarkan perbedaan kejadian stres pasca trauma pada ibu post partum dengan sectio caesarea emergency dan partus spontan dengan menggunakan metode pendekatan cross sectional. Populasi penelitian adalah semua pasien post partum primigravida di Rumah Sakit sejumlah 60 orang yang terdiri dari $30 \mathrm{ibu}$ post partum sectio caesarea emergency dan 30 ibu post partum normal. Sampel dalam penelitian ini adalah total populasi yaitu semua pasien post partum primigravida di Rumah Sakit $30 \mathrm{ibu}$ post partum sectio caesarea emergency dan 30 ibu post partum normal. Variabel dependen/terikat pada penelitian ini adalah stres pasca trauma. Variabel independent/bebas pada penelitian ini adalah persalinan sectio caesarea emergency dan partus spontan.

Pengumpulan data dilakukan dengan menggunakan kuesioner tentang stress pasca trauma dengan menggunakan skala post-traumatic stress disorder dari Dadang Hawari. Pengumpulan akan dilakukan selama 1 bulan oleh peneliti dan dibantu oleh 2 orang perawat ruangan yang terlebih dahulu telah diberi penjelasan tentang proses penelitian. Data akan diolah melalui proses editing, coding, proccessing dan cleaning. Selanjutnya data dianalisis secara univariat untuk mendapatkan gambaran statistik deskriptif dari masing-masing variabel, baik variabel independen maupun dependen dan bivariat dengan uji $t$-independent.
HASIL

\section{Analisis Univariat}

Tabel 1: Distribusi Kejadian Stres Pasca Trauma pada Ibu Post Partum dengan Sectio Caesarea Emergency

\begin{tabular}{lcc}
\hline $\begin{array}{c}\text { Stres Pasca Trauma } \\
\text { Sectio Caesar Emergency }\end{array}$ & $\mathrm{f}$ & $\%$ \\
\hline Normal & 13 & 43,3 \\
\hline Ringan & 6 & 20,0 \\
\hline Sedang & 11 & 36,7 \\
\hline \multicolumn{1}{c}{ Jumlah } & 30 & 100,0 \\
\hline
\end{tabular}

Berdasarkan tabel di atas diketahui bahwa sebagian besar responden tidak mengalami stress yaitu 13 responden $(43,3 \%)$, namun ditemukan terdapat responden dengan stress sedang yaitu 11 responden $(36,7 \%)$.

Tabel 2: Distribusi Kejadian Stres Pasca Trauma pada Ibu Post Partum dengan Partus Spontan

\begin{tabular}{ccc}
\hline $\begin{array}{c}\text { Stres Pasca Trauma } \\
\text { Partus Spontan }\end{array}$ & $\mathrm{f}$ & $\%$ \\
\hline Normal & 28 & 93,3 \\
\hline Ringan & 2 & 6,7 \\
\hline Jumlah & 30 & 100,0 \\
\hline
\end{tabular}

Berdasarkan tabel di atas diketahui bahwa sebagian besar responden tidak mengalami stress yaitu 28 responden $(93,3 \%)$, dan responden dengan stress ringan yaitu 2 responden $(6,7 \%)$.

\section{Analisis Bivariat}

Tabel 3: Distribusi Perbedaan Stres Pasca Trauma pada Ibu Post Partum dengan Sectio Caesarea Emergency dan Partus Spontan

\begin{tabular}{lcccc}
\hline \multicolumn{1}{c}{$\begin{array}{c}\text { Stres Pasca } \\
\text { Trauma }\end{array}$} & Mean & SD & $\begin{array}{c}\rho- \\
\text { value }\end{array}$ & $\mathrm{n}$ \\
\hline $\begin{array}{l}\text { Sectio Caesarea } \\
\text { Emergency }\end{array}$ & 16,7 & 4,95 & 0,000 & $\frac{30}{30}$ \\
\hline Partus Spontan & 10,1 & 3,39 & & 30 \\
\hline
\end{tabular}


Hasil penelitian didapatkan bahwa rata-rata tingkat stress pasca trauma pada ibu yang melakukan persalinan dengan Sectio Caesar emergency adalah 16,7, dengan SD 4,95. Sedangkan rata-rata tingkat stress pasca trauma pada ibu yang melakukan persalinan dengan persalinan normal adalah 10,1, dengan SD 3,39, sehingga dapat disimpulkan bahwa ada perbedaan rata-rata tingkat stress pasca trauma pada ibu yang melakukan persalinan dengan sectio caesar emergency dan pada ibu yang melakukan persalinan normal. Hasil uji statistik didapatkan nilai $\rho=0,000$ (p hitung $<\alpha$ ), artinya pada $\alpha=5 \%$ dapat diartikan ada perbedaan kejadian stres pasca trauma pada ibu post partum dengan sectio caesarea emergency dan partus spontan.

\section{PEMBAHASAN}

\section{Stres Pasca Trauma pada Ibu Post Partum dengan Sectio Caesarea Emergency}

Hasil penelitian menunjukkan bahwa sebagian besar responden tidak mengalami stress yaitu 13 responden (43,3\%), namun ditemukan terdapat responden dengan stress sedang yaitu 11 responden $(36,7 \%)$.

Emergency dalam persalinan merupakan tindakan persalinan buatan, salah satu tindakan tersebut adalah persalinan sectio caesarea. Persalinan sectio caesarea merupakan persalinan buatan dimana janin dilahirkan melalui suatu insisi pada dinding perut dan dinding rahim dengan saraf rahim dalam keadaan utuh serta berat diatas 500 gr (Kaplan \& Sadock, 2007). Kelahiran melalui sectio caesarea dapat berisiko menimbulkan gangguan fisiologis dan psikologis terutama pada sectio caesarea yang tidak direncanakan atau bersifat tidak direncanakan (Connor \& Butterfield, 2003).

Sectio caesarea memiliki dampak pada psikologis ibu. Ibu yang persalinan dengan sectio caesarea yang tidak direncanakan (emergency) mengekspresikan kekhawatiran praoperatif seperti takut akan kematian, takut akan keselamatan hidup bayinya, anestesi dan kamar operasi (Somera, dkk, 2010). Ibu tertekan pada sebelum, selama dan sesudah SC yang dialami yaitu mengekspresikan kurangnya kepuasan dan persepsi yang negatif terhadap SC. Ibu sering mengalami kekhawatiran psikososial dan fisik. Ibu mengeluhkan perasaan takut, hilangnya konsentrasi, mudah marah, kecemasan dan gangguan persepsi tentang sectio caesarea . Pada wanita sectio caesarea yang tidak direncanakan cenderung melaporkan nyeri pada postoperative dan persepsi melahirkan yang negative (Cranley dkk, 2012). Selain itu, psikologis ibu muncul psikososialnya seperti kecemasan, harga diri, dan depresi yang memiliki berbagai pengaruh pada persepsi melahirkan yang terkait dengan sectio caesarea yang tidak direncanakan. Dampak lain setelah sectio caesarea terjadinya, gangguan stres pasca trauma (PTSD) dan depresi postpartum. Selain itu, komplikasi psikologis lain yang terkait dengan awal interaksi ibu dengan bayi serta peran pencapaian ibu (Weems CF, Reiss Al 2007).

Sejalan dengan penelitian ini, penelitian Permatasari (2011) tentang Perbedaan Kejadian Postpartum Blues Pada Persalinan sectio caesarea dan Persalinan Spontan, respodem dengan persalinan seksio sesaria yang tidak mengalami postpartum blues sebanyak 14 orang $(21,2 \%)$ dan ada (mengalami) postpartum blues sebanyak 19 orang $(28,8 \%)$.

Menurut peneliti timbulnya stres fisik dan psikologis terkait dengan sectio caesarea dapat mengakibatkan krisis emosional yang berdampak pada kesehatan ibu dan bayi serta mempengaruhi integrasi keluarga dan menghambat ikatan emosional ibu dan bayi. Stressor yang dirasakan oleh responden dalam penulisan ini terkait dengan respon terhadap harus dilakukannya sectio caesarea, respon psikologis terhadap persiapan operasi sectio caesarea dan stimulus yang 
memicu stress. Respon terhadap harus dilakukannya sectio caesarea ini menimbulkan perasaan cemas (khawatir). Kecemasan yang terjadi pada responden dalam penelitian ini disebabkan karena kekhawatiran pertama kali operasi sectio caesarea, membayangkan peralatan untuk operasi, operasi tidak lancar dan anak tidak selamat. Kecemasan praoperatif merupakan respon antisipasi terhadap pengalaman yang dianggap sebagai ancaman terhadap peran dalam hidup, integritas tubuh atau bahkan kehidupannya sendiri dan janinnya. Informasi yang lengkap tentang anestesi, sectio caesarea dan dukungan emosional dari pasangan merupakan faktor-faktor yang dapat menurunkan kecemasan serta meningkatkan kepuasan ibu terhadap sectio caesarea yang dialaminya

\section{Stres Pasca Trauma pada Ibu Post Partum dengan Partus Spontan}

Hasil penelitian menunjukkan bahwa sebagian besar responden tidak mengalami stress yaitu 28 responden $(93,3 \%)$, dan responden dengan stress ringan yaitu 2 responden $(6,7 \%)$.

Stres yang muncul pada perempuan yang baru melahirkan karena perubahan hormonal setelah melahirkan, yaitu pengaruh perubahan hormon estrogen dan progesterone. Pada perempuan post SC, postpartum blues ini muncul karena pengaruh hormon kortisol. Hormon kortisol ini seperti diketahui meningkat selama hamil dan setelah operasi yang berakibat pada perubahan mood. Disforia yang terjadi karena peningkatan hormon kortisol yang menyebabkan hormon adrenal makin meningkat karena stres.

Sejalan dengan penelitian ini, penelitian Permatasari (2011) tentang Perbedaan Kejadian Postpartum Blues Pada Persalinan Seksio Sesaria Dan Persalinan Spontan, Responden dengan persalinan spontan yang tidak mengalami postpartum blues sebanyak 24 orang $(36,40 \%)$ dan ada (mengalami) postpartum blues sebanyak 9 orang $(13,6 \%)$.
Menurut peneliti kejadian stress pada ibu post partum normal karena sedikit atau tidak ada sama sekali bantuan dalam merawat anak. Hal tersebut dapat terjadi pada setiap perempuan, baik pada perempuan primipara maupun multipara. Stres yang dialami perempuan setelah melahirkan juga disebabkan kurangnya pengetahuan perempuan yang baru melahirkan terhadap tugas-tugas baru yang harus dijalani sebagai seorang ibu, jadi bukan dikarenakan oleh proses persalinan yang baru dialaminya, karena sekalipun proses yang dialami panjang dan melelahkan dapat dilupakan dengan berhasilnya ibu melakukan persalinan secara normal.

\section{Perbedaan Stres Pasca Trauma pada Ibu Post Partum dengan Sectio Caesarea Emergency dan Partus Spontan}

Ada perbedaan kejadian stres pasca trauma pada ibu post partum dengan sectio caesarea emergency dan partus spontan di Rumah Sakit ( $p$-value $=0,000)$.

Menurut Evariany (2007) yang menyatakan bahwa tingginya kejadian stres ibu setelah melakukan persalinan pada umumnya terjadi terhadap ibu dengan persalinan spontan, karena persalinan ini tidak direncanakan sama sekali, sehingga kesiapan ibu baik secara fisik maupun psikologis belum siap, sehingga berdampak terhadap stabilitas emosi atau perasaan dan kecemasan yang pada akhirnya menjadi pencetus terjadinya stress.

Persalinan seksio sesaria adalah suatu persalinan buatan di mana janin dilahirkan melalui suatu insisi pada dinding perut dan dinding Rahim dengan syarat rahim dalam keadaan utuh serta berat janin di atas 500 gram. Selain itu ada pertimbangan lain yang digunakan sebagai indikasi seksio sesaria yaitu ibu dengan risiko tinggi persalinan. Komplikasi yang terjadi pada tindakan ini menyebabkan trauma jaringan baik pada ibu maupun janin. Trauma jaringan (fisik) pada ibu dapat mengakibatkan nyeri pasca 
seksio sesaria akut yang dapat mengganggu kondisi fisik dan psikologis sang ibu. Menurut Patel (2005) dan Sword (2009) menyatakan bahwa perawatan di rumah sakit yang lebih lama, biaya yang lebih mahal, serta penundaan ke aktivitas normal yang lebih lama dapat mempengaruhi gangguan psikologis pada ibu, yaitu depresi pasca persalinan.

Hasil yang diperoleh pada penelitian ini sesuai dengan penelitian yang dilakukan oleh Cury (2008), stres pasca trauma yang muncul pada perempuan post operatif (SC) terlihat lebih nyata dibandingkan dengan perempuan yang melahirkan secara normal. Perbedaan sangat nyata terlihat dari waktu munculnya gejala stres pasca trauma. Pada perempuan yang melahirkan secara normal, gejala stres pasca trauma terlihat memuncak di hari ke tiga dan empat, sedangkan pada perempuan post sectio caesarea gejala-gejala stres pasca trauma muncul segera setelah operasi dan menghilang secara progresif. Menurut Iles (1989), perempuan yang menjalani kelahiran dengan sectio caesarea lebih berisiko mengalami gangguan mood setelah melahirkan di awal masa postpartum dibandingkan perempuan yang menjalani persalinan spontan. Hal tersebut karena stres akibat proses pembedahan yang dilakukan, yang mengakibatkan perubahan pada sistem endokrin dan psikologis di masa puerpurium sehingga berakibat berkembangnya stres pasca trauma yang lebih nyata terlihat (Stig, 2001).

Stres pasca trauma yang muncul pada perempuan yang baru melahirkan karena perubahan hormonal setelah melahirkan, yaitu pengaruh perubahan hormon estrogen dan progesteron (Kennerley, 1989). Menurut Levy (1987), pada perempuan post sectio caesarea, stres pasca trauma ini muncul karena pengaruh hormon kortisol. Hormon kortisol ini seperti diketahui meningkat selama hamil dan setelah operasi yang berakibat pada perubahan mood. Disforia yang terjadi karena peningkatan hormon kortisol yang menyebabkan hormon adrenal makin meningkat karena stres. Stres pasca trauma merupakan disforia yang terjadi sebagai reaksi akibat dari stres akut setelah mengalami proses operasi dan karena trauma fisik akibat pembedahan.

Hasil penelitian Isdinawati (2000) menyebutkan kecenderungan depresi postpartum perempuan primipara lebih tinggi dibandingkan perempuan multipara. Perempuan primipara belum mempunyai pengalaman dalam merawat anak sehingga timbul rasa takut dan khawatir melakukan kesalahan dalam merawat bayi. Begitu pula dalam melakukan tugas sebagai seorang ibu, wanita primipara merasa bingung, lebih terbebani, dan merasa kebebasannya berkurang dengan hadirnya seorang anak (Isdinawati, 2000).

Menurut Freudenthal (1999), stres pasca trauma yang dialami seorang perempuan setelah melahirkan terjadi karena sedikit atau tidak ada sama sekali bantuan dalam merawat anak. Hal tersebut dapat terjadi pada setiap perempuan, baik pada perempuan primipara maupun multipara. Stres pasca trauma yang dialami perempuan setelah melahirkan juga disebabkan kurangnya pengetahuan perempuan yang baru melahirkan terhadap tugas-tugas baru yang harus dijalani sebagai seorang ibu (Hunker, 2007).

Menurut Fisher (1997) bahwa perempuan yang menjalani seksio sesaria emergency akan mengalami perasaan gagal dan penurunan harga diri lebih besar karena tidak dapat melahirkan dengan normal serta tidak memiliki persiapan sebelumnya. Kelahiran dengan prosedur seksio sesaria emergency akan membawa dampak psikologis yang negatif bagi perempuan setelahnya dibandingkan perempuan yang menjalani seksio sesaria elektif. Perempuan yang menjalani sectio caesarea elektif, persiapan telah dipersiapkan sebelumnya karena mendapat informasi dari tenaga kesehatan. Perempuan yang menjalani seksio sesaria elektif akan menerima informasi mengenai proses sectio caesarea, waktu yang dibutuhkan, dan risiko yang kemungkinan muncul setelahnya dari staf kesehatan sewaktu pemeriksaan antenatal care. 
Proses informasi yang diterima akan membuat wanita yang menjalani sectio caesarea elektif mempersiapkan diri lebih baik secara fisik maupun mental serta proses penyembuhannya akan lebih cepat dan tidak menimbulkan trauma yang berat seperti pada wanita yang menjalani sectio caesarea emergency (Churcill, 2005).

Perempuan yang menjalani sectio caesarea emergency tidak mengetahui sebelumnya bahwa kehamilannya harus diakhiri dengan sectio caesarea. Pemberitahuan bahwa proses persalinan akan dilakukan dengan sectio caesarea dilakukan sesaat sebelum proses operasi, sehingga perempuan yang menjalani sectio caesarea emergency tidak dapat mengantisipasi perasaannya (Churcill, 2005). Perempuan yang mejalani seksio sesaria emergency tidak memiliki persiapan dan pengetahuan yang cukup mengenai sectio caesarea dan dampak yang ditimbulkan setelah sectio caesarea. Seorang perempuan yang menjalani sectio caesarea emergency akan merasa lebih takut akan kematian atau terluka, takut kehilangan bayinya, serta kehilangan kesadaran seterusnya akibat penggunaan anestesi (loss contact with reality) karena tidak pernah terpikirkan akan melahirkan dengan sectio caesarea sebelumnya (Ryding, 2000).

Menurut peneliti trauma akan kelahiran dengan proses operasi tanpa pemberitahuan sebelumnya merupakan salah satu penyebab stres pasca trauma. Selain karena trauma, proses pemisahan dengan bayi yang baru dilahirkan yang belum diantisipasi sebelumnya membuat kekhawatiran perempuan yang menjalani sectio caesarea emergency bertambah. Sebagian besar perempuan yang menjalani sectio caesarea, mempunyai masalah pada keadaan ibu dan bayinya sehingga keadaan keduanya setelah proses persalinan akan dipisahkan sampai keadaan keduanya stabil. Banyak wanita yang merasa cemas dan khawatir dengan keadaan fisik bayinya.

\section{KESIMPULAN}

Rata-rata tingkat stress pasca trauma pada ibu yang melakukan persalinan dengan sectio caesar emergency adalah 16,7, dengan SD 4,95. Rata-rata tingkat stress pasca trauma pada ibu yang melakukan persalinan dengan persalinan normal adalah 16,7, dengan SD 3,39. Ada perbedaan kejadian stres pasca trauma pada ibu post partum dengan sectio caesarea emergency dan partus spontan dengan $p$-value 0,000 .

Disarankan

melakukan pendampingan memberikan support bagi ibu post sectio caesarea emergency, serta menganjurkan keluarga untuk memberikan dukungan kepada ibu sehingga stress yang dirasa tidak memanjang sehingga timbul masalah depresi pasca persalinan. Perlu dilakukan intervensi khusus seperti penyuluhan dan pendampingan untuk menurunkan derajat depresi pasca persalinan pada pada perempuan postpartum. Perlu dilakukan penelitian lebih lanjut mengenai perbedaan stres pasca trauma primipara dengan persalinan spontan dan sectio caesarea dengan mengendalikan faktor-faktor luar yang turut mempengaruhi, seperti genetik, kepribadian, hormon, dukungan keluarga, riwayat kehamilan dan sosial ekonomi yang belum dapat dikendalikan dalam penelitian ini.

\section{DAFTAR PUSTAKA}

Connor \& Butterfield. (2003). Post traumatic stress disorder. Summer 2003, 1 (3), 249-262. http://focus.psychiatryonline.org/cgi/ reprint/1/3/247

Czarnocka, J. \& Slade, P. (2000). Prevalence and predictors of posttraumatic stress symptoms following childbirth. British Journal of Clinical Psychology, 39, 35-51.

Dinkes Provinsi Lampung (2012). Profil Dinas Kesehatan Provinsi Lampung Tahun 2011. Dinas Kesehatan Provinsi Lampung. 
Evariny, A. (2007 ). Trauma Kehamilan dan Pengaruhnya pada Janin. Diperoleh dari http://www.hypnobirthing.com

Hamid, A.Y. S. (1997). Bunga Rampai Asuhan Keperawatan Kesehatan Jiwa. Jakarta: Penerbit EGC

Kaplan \& Sadock. (2007). Sinopsis Psikiatri: Ilmu Pengetahuan Psikiatri Klinis. (Jilid 1). Jakarta: Bina Rupa Aksara

Kemenkes RI. (2015). Profil Kesehatan Indonesia Tahun 2015.

Loveland-Cook, C.A., Flick, L.H., Homan, S.M., Campbell, C., McSweeney, M., \& Gallagher, M.E. (2004). Posttraumatic Stress Disorder In Pregnancy: Prevalence, Risk Factors, And Treatment. Obstet Gynecol, 710-717
Mulyawati, (2011). Faktor Tindakan Persalinan Operasi Sectio Caesarea. https://journal.unnes.ac.id/nju/index. $\mathrm{php} / \mathrm{kemas} /$ article/viewFile/1788/19 $\underline{79}$

Permatasari. (2011). Perbedaan Kejadian Postpartum Blues Pada Persalinan Seksio Sesaria Dan Persalinan Spontan

Sussman, D. (2000). A spiritual approach: Nurses and chaplains team up to provide pastoral care. Healthweek, 5 (12), 12.

Weems CF, Reiss AL. (2007). Stres, Posttraumatic Stres Disorder, and the HippocampusStres Predicts Brain Changes in Children: A Pilot Longitudinal Study on Youth. Pediatry;19:509-516 